\title{
Colonisation patterns and vertical movements of stream invertebrates in the interstitial zone: a case study in the Apennines, NW Italy
}

\author{
Tiziano Bo, Marco Cucco, Stefano Fenoglio* \& Giorgio Malacarne \\ University of Piemonte Orientale, Di.S.A.V., Via Bellini 25, I-15100, Alessandria, Italy \\ (*Author for correspondence: Tel.: + 390131 360201; Fax: + 390131 360219; E-mail: fenoglio@unipmn.it)
}

Received 25 October 2005; in revised form 16 January 2006; accepted 21 January 2006; published online 17 June 2006

Key words: interstitial zone, macroinvertebrates, colonisation, vertical movements

\begin{abstract}
We examined vertical migration and colonisation patterns of stream macroinvertebrates within the substratum of an Apennine creek in NW Italy. Macrobenthos was sampled at three depths in the streambed $(0-5,5-10,10-15 \mathrm{~cm})$ by means of artificial baskets filled with natural substratum. We placed 42 traps $(5 \times 5 \times 15 \mathrm{~cm})$, i.e. 21 top-opened (T-traps) and 21 bottom-opened (B-traps), each composed of three overlapping baskets (high-H, medium-M and low-L), to evaluate differences in the vertical movements. We also collected Surber samples to compare interstitial assemblages with streambed communities. The multilevel traps yielded 42 taxa, compared with 60 taxa in the natural riverbed. Interstitial traps were rapidly colonised; both taxa richness and organism number increased during the 42-day study period. We found active migration in both vertical directions, but there were more invertebrates in the top-opened traps than in the bottom-opened traps. In the T-traps the most colonised baskets were those placed at the $\mathrm{H}$ level, while in the B-traps the L level baskets were more rapidly colonised. The interstitial assemblages differed markedly from the streambed communities in both composition and functional organisation, with more collector-gatherers and predators in the interstitial zone and more filterers and scrapers in the natural riverbed. In Apennine lotic systems, the interstitial zone is an important habitat for stream macrobenthos, although it may not be used by all species.
\end{abstract}

\section{Introduction}

There is growing interest in the vertical dimension of stream systems. Traditionally, aquatic ecologists have perceived streams and rivers as bounded systems, consisting of riverbeds and overlying water; the exchanges of water, detritus, nutrients and organisms between groundwater and stream channels have only recently become a central element in freshwater ecology (e.g. Hynes, 1974; Bretschko, 1979, 1981，1985，1990，1994，1995; Vallet et al., 1993). Orghidan (1959) considered the hyporheic zone as the sub-surface region of lotic systems that exchanges water with the surface. In a more recent perspective, White (1993) considered the hyporheic zone as the saturated interstitial areas beneath the riverbed and in the stream banks that contain some proportion of channel water or that have been altered by channel water infiltration: this is a functional interface between groundwater and surface-water ecosystems. The riverbed represents the upper part of this hyporheic zone and it plays an important role in the functioning of lotic ecosystems (Bretschko, 1992, 1994, 1995; Weigelhofer \& Waringer, 2003). Following DoleOlivier \& Marmonier (1992), we will use the term 'interstitial habitat' instead of hyporheic zone to indicate the permeable area of the substratum.

It is well known that the interstitial zone acts as a refuge for benthic macroinvertebrates, increasing 
both the resistance and resilience of stream macroinvertebrate communities (Dole-Olivier et al., 1997). Benthic macroinvertebrates are focal elements of lotic environments, playing a fundamental role in the functioning of the river and in maintenance of its self-purifying capacity (Vannote et al., 1980). The water flowing in the riverbed pore system constitutes an essential and peculiar habitat that may support rich and diversified macroinvertebrate assemblages (Giller \& Malmqvist, 1998). Many invertebrate taxa use the interstitial area as a nursery zone, for the deposition and incubation of eggs and the growth of small instars (Jacobi \& Cary, 1996), or as refuge, suggesting that macroinvertebrates migrate into the hyporheic zone to survive catastrophic hydrological events (Dole-Olivier et al., 1997) and to escape high surface water temperatures (Boulton et al., 1998) or droughts (Boulton, 1989). For these reasons, estimates of secondary production in streams are substantially greater when the interstitial fauna is included in the calculations: for example, Huryn (1996) demonstrated that the total benthos production was sufficient to explain the observed fish production in a New Zealand stream only when the sub-substratum production was taken into account.

Despite the growing interest in the subsubstratum zone, few studies have investigated the direction and patterns of within-substrate movements in the first layer of the riverbed. Early studies on movements and colonisation patterns of stream organisms showed that freshwater invertebrate populations are in continuous redistribution (Townsend \& Hildrew, 1976). Williams \& Hynes (1976) detected four main colonisation patterns. (1) Drift, the "downstream transport of aquatic organisms in the current", is probably the main component of the colonisation process for most taxa (Brittain \& Eikeland, 1988; Mackay, 1992), also in Apennine lotic systems (Fenoglio et al., 2004). (2) Upstream movement within the water has been recorded for many benthic invertebrates (Söderström, 1987; Panek, 1991). In a recent study of a NW Italian river, Fenoglio et al. (2002) detected evident seasonal influences in this process,involving many taxa such as Brachyptera sp. (Plecoptera, Taenioperygidae), Capnia sp. (Plecoptera, Capniidae) and others. (3) The upstream flight of lotic insects is also an important component of the colonisation cycle of many taxa. Muller's pioneering theory (1954) of the colonisation cycle of freshwater insects in lotic systems identified the upstream flight of imagines as compensation for the downstream displacement of immature individuals via drift. This idea was confirmed by studies demonstrating a pronounced tendency of egg-bearing females to fly upstream (Madsen \& Butz, 1976; Muller, 1982). (4) Vertically upward movement from within the substrate is another important colonisation mechanism. Although generally neglected for a long time, this process is now attracting growing interest. However: (a) many studies have focused on the importance of downward movement towards the hyporheic/interstitial zone, especially in temporary streams (Delucchi, 1989) in which flow occurs either seasonally (intermittent streams) or in response to irregular rain (episodic streams) (Hose et al., 2005); (b) despite the great ecological importance of the sub-substratum zone, studies on ecological and functional aspects of interstitial areas have been performed only in recent years (Marmonier et al., 1992); (c) traditionally, most investigators have studied the meiofauna, while ecological aspects of the macrofauna in the interstitial zone have only been investigated in a few studies. The long-term RITRODAT-Lunz project was one of the most important efforts in this field (Bretschko, 1981).

The aims of the present experimental study were: (a) to provide data about colonisation patterns and vertical migration of stream macroinvertebrates in the interstitial zone; (b) to analyse the composition, structure and functional organisation of interstitial assemblages; (c) to investigate the importance of the sub-substratum as a habitat for the benthic communities of an Apennine river, a system not studied thus far.

\section{Methods}

This study was conducted in the Caramagna Creek, a small tributary of the Bormida River, NW Italy $\left(44^{\circ} 36^{\prime} \mathrm{N}-8^{\circ} 32^{\prime} \mathrm{E}\right.$; altitude $280 \mathrm{~m}$ asl; Fig. 1). Dense woodlands, with small scattered urban areas, cover the catchment. This lotic system is of good environmental quality, reaching First Class in the Extended Biotic Index system 


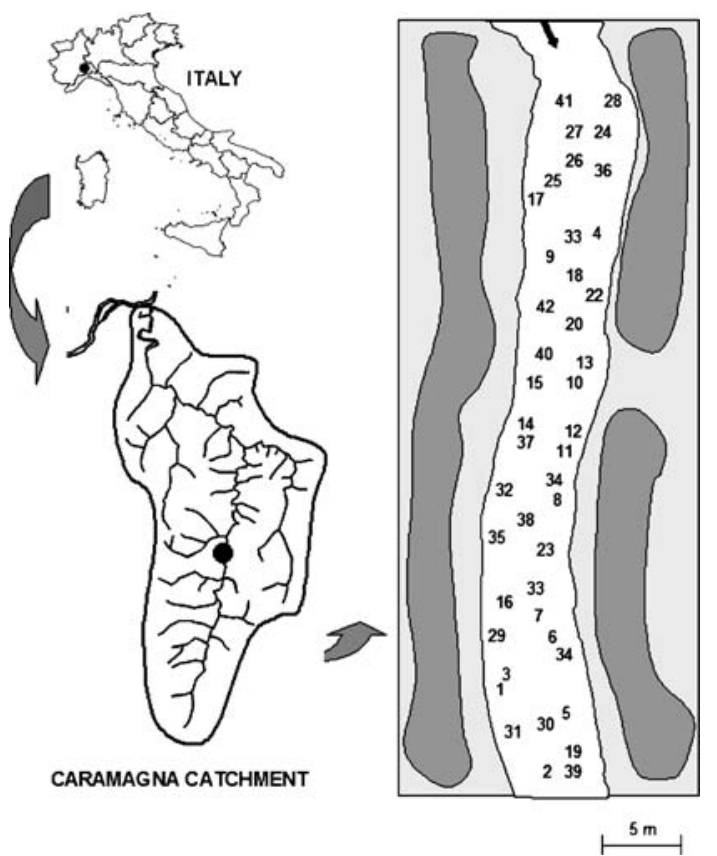

Figure 1. Location of Caramagna Creek (NW Italy) and interstitial traps position in the riffle.

(Ghetti, 1997), corresponding to an environment without human impact. Table 1 reports some abiotic parameters, measured with Eijkelkamp 13.14 and 18.28 portable instruments (parameters were measured at each sampling date).

On December 29, 2004, we placed 42 vertical stratification samplers in a large and uniform gravel riffle of the Caramagna Creek riverbed, using a random distribution. The traps consisted of a parallelepiped metal net (mesh size $1 \mathrm{~cm}$ ), measuring $5 \mathrm{~cm}$ long, $5 \mathrm{~cm}$ wide and $15 \mathrm{~cm}$ high (Fig. 2). Two $5 \times 5 \mathrm{~cm}$ frames were inserted to separate three overlapping $5 \times 5 \times 5 \mathrm{~cm}$ baskets $(\mathrm{H}$, M, L, i.e. High, Medium and Low level). The traps

Table 1. Conductivity, dissolved oxygen, $\mathrm{pH}$ and flow speed $($ mean $\pm \mathrm{SD})$ of the surface water in the stream reach during the study period

\begin{tabular}{lr}
\hline Parameter & \multicolumn{1}{l}{ Values } \\
\hline Conductivity $(\mu \mathrm{S} / \mathrm{cm})$ & $359.0 \pm 32.2$ \\
Dissolved oxygen $(\mathrm{mg} / \mathrm{l})$ & $8.30 \pm 0.18$ \\
$\mathrm{pH}$ & $8.63 \pm 0.21$ \\
Water velocity $(\mathrm{m} / \mathrm{s})$ & $0.60 \pm 0.20$ \\
Temperature $\left({ }^{\circ} \mathrm{C}\right)$ & $2.87 \pm 1.42$ \\
\hline
\end{tabular}

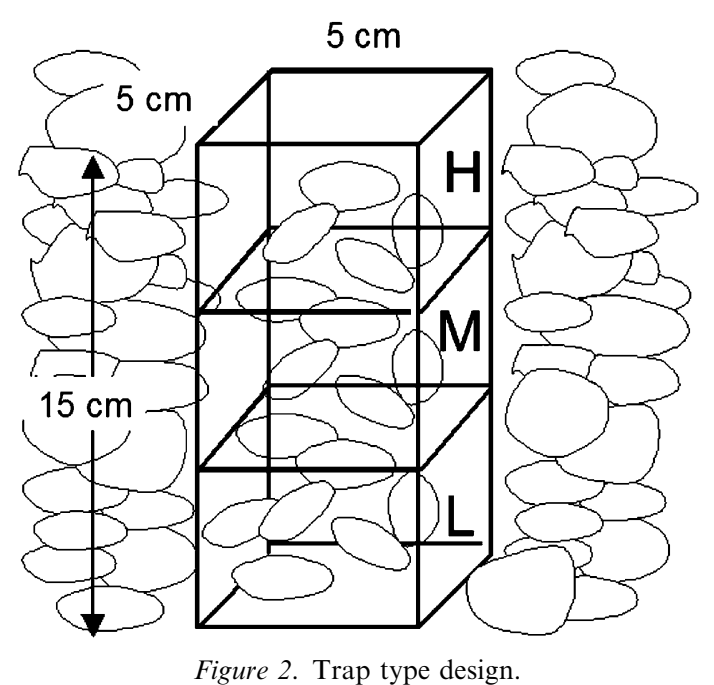

were filled with clean, sterile substratum according to the granulometry of the riffle (Md approximately 9.5). Traps were individually numbered: traps 1-21 (T-traps = top-opened traps) were covered with nylon net (mesh size $265 \mu \mathrm{m}$ ) except for the apex, allowing access exclusively from the top. Traps 22-42 (B-traps = bottom-opened traps) were covered with the same net, but in this case the only access was from the bottom. The traps were left in place for a maximum of 42 days. This period was long enough to allow macroinvertebrates to reach maximum abundance, as indicated by the literature (Hauer \& Lamberti, 1996) and a previous experiment in a nearby area (Fenoglio et al., 2002), and short enough to avoid floods. After 14, 28 and 42 days, we randomly selected 14 traps per sampling date (seven top-opened and seven bottom-opened) from the stream in order to investigate the colonisation process. The macroinvertebrates dislodged from each trap when it was moved were collected with a $250 \mu \mathrm{m}$ mesh net and added to the sample.

To quantify the macroinvertebrate community composition and structure on the natural bottom of the river, we used a $0.06 \mathrm{~m}^{2}$ sampler with a $250 \mu \mathrm{m}$ mesh to collect 30 Surber samples in the same riffle area where we placed the traps. The Surber samples were randomly collected on three dates during the experiment (day 1, day 15 and day 35$)$.

In the laboratory, all organisms were counted and identified to the genus level, except for 
Chironomidae, Simuliidae and early instars of some Trichoptera and Diptera, which were identified to the family level. Each taxon was also assigned to a Functional Feeding Group (FFG: scrapers, shredders, collector-gatherers, filterers and predators) according to Merritt \& Cummins (1996). Moreover, a classification of taxa into seven biological and seven ecological groups was conducted according to the Usseglio-Polatera et al. (2000) species traits approach.

Statistical analysis of the total number of macroinvertebrates and the taxa richness of samples collected in T-traps and B-traps was performed with ANOVA of log-transformed data. For comparison of the functional composition, we used arcsin-transformed data of FFG percentage composition.

Richness accumulation curves, generated with EstimateS 6.0 software (Colwell, 1997), were used to compare the cumulative taxa number for all samples from $\mathrm{T}$ - and B-traps. The preference of individual taxa to enter B- or T-traps was evaluated by indicator species analysis computed with INDVAL 2.0 software (Dufrêne, 1998). Indicator species analysis is a randomisation-based test that compares the relative abundance and relative frequency of taxa to find indicator species assemblages characterising groups of samples. A taxon's affinity for a sampling group is expressed as a percentage (Dufrêne \& Legendre, 1997).

\section{Results}

Data for colonisation density and taxa richness in each trap category and in the Surber samples are reported in Table 2. The total abundance of macroinvertebrates significantly increased over time (Fig. 3) in both the T-traps $\left(F_{2}, 20=20.15\right.$, $p<0.001)$ and B-traps $\left(F_{2}, 20=11.4, p=0.001\right)$. Community richness significantly increased over time in both trap types (T-traps: $F_{2,20}=15.55$, $p<0.001$; B-traps: $F_{2,20}=4.13, p=0.033$ ).

Top-opened traps were more rapidly colonised, with a higher number of organisms in the first period, while later there were no significant differences in macroinvertebrate abundance (Table 3 ). Taxa richness increased over time (Fig. 3), with a significant difference between B- and T-traps in the last sampling period (Table 3 ). Species accumula- tion curves showed that additional taxa were likely to be found with additional sampling (Fig. 4). The curves agree with the other data in that T-traps showed greater taxa richness.

The baskets closest to the trap opening ( $\mathrm{H}$ for T-traps, L for B-traps) were the most colonised, considering both the number of individuals (Fig. 5, ANOVA $\left.F_{2,124}=4.26, p=0.016\right)$ and the number of taxa (ANOVA $F_{2,124}=3.37, p=0.038$ ). Hence, the most colonised baskets in the T-traps were those placed at the $\mathrm{H}$ level, while in the B-traps the L level baskets were most rapidly colonised. Differences between the $\mathrm{H}, \mathrm{M}$ and L baskets were present in the first two sampling periods (14 and 21 days), but after 42 days the H, M and L baskets showed similar invertebrate abundance (Fig. 5) and taxa richness.

The most abundant taxa in both the T- and B-trap assemblages were Chironomidae, Dugesia sp., Limnephilidae (small instars), Eiseniella tetraedra, Capnia bifrons, Brachyptera sp. and Baetis sp. Comparison of assemblages in the two trap types by indicator species analysis revealed two taxa with a significant preference for topdown vertical movement, Capnia bifrons and Baetis sp., and one taxon, Brachyptera sp., with a bottom-top preference. There were no precocious colonisers, but we detected some late colonisers, i.e. taxa particularly present in the last phase of the experiment: Baetis sp., Capnia bifrons, Eiseniella tetraedra, Helicus substriatus and Limnephilidae. Indicator values, habitat abundance and fidelity of significant taxa $(p<0.05)$ are summarised in Table 4.

Interestingly, although some groups were abundant and widespread on the river bottom, they were absent or rare in the interstitial traps: in particular, the black flies (Simuliidae) were abundant throughout the whole riffle, with a mean density of 1026 ind. $/ \mathrm{m}^{2}$ in some areas, as was the mayfly Ecdyonurus sp. with a mean density of 52.5 ind. $/ \mathrm{m}^{2}$. A similar pattern was observed for some water bugs (Micronecta sp.) and caddisflies (Hydropsyche sp.).

The most abundant FFG in the interstitial traps was collector-gatherers $(50.7 \%$ in $\mathrm{T}$-traps and $44.5 \%$ in B-traps), followed by predators (18.9\% in $\mathrm{T}$-traps and $34.1 \%$ in B-traps) and shredders $(22.9 \%$ in T-traps and $16.2 \%$ in B-traps), while scrapers were not abundant $(6.5 \%$ in T-traps and $4.0 \%$ in B-traps) and filterers 
Table 2. Percent relative abundance for macroinvertebrates collected in the natural riverbed and from Bottom (B) and Top (T) opened interstitial traps

\begin{tabular}{|c|c|c|c|c|c|c|}
\hline Taxa & Biol. traits & Ecol. traits ${ }^{\mathrm{a}}$ & $\mathrm{FFG}^{\mathrm{b}}$ & Natural riverbed & B-Traps & T-Traps \\
\hline \multicolumn{7}{|l|}{ Plecoptera } \\
\hline Capnia bifrons & $\mathrm{e}$ & $\mathrm{B}$ & Sh & 0.48 & 2.79 & 6.37 \\
\hline Leuctra sp. & $\mathrm{f}$ & B & Sh & 0.73 & 0.00 & 0.98 \\
\hline Nemoura sp. & $\mathrm{f}$ & A & Sh & 0.30 & 0.56 & 1.96 \\
\hline Brachyptera sp. & $\mathrm{f}$ & $\mathrm{B}$ & $\mathrm{Sh}$ & 21.07 & 5.03 & 1.96 \\
\hline Isoperla $\mathrm{sp}$ & $\mathrm{c}$ & $\mathrm{B}$ & $\mathrm{P}$ & 0.73 & 0.00 & 0.00 \\
\hline \multicolumn{7}{|l|}{ Ephemeroptera } \\
\hline Ecdyonurus sp. & $\mathrm{f}$ & $\mathrm{C}$ & $\mathrm{Sc}$ & 1.36 & 0.00 & 1.47 \\
\hline Baetis sp. & $\mathrm{e}$ & $\mathrm{C}$ & $\mathrm{Cg}$ & 7.41 & 2.79 & 4.90 \\
\hline Caenis sp. & $\mathrm{f}$ & $\mathrm{F}$ & $\mathrm{Cg}$ & 0.11 & 0.56 & 0.00 \\
\hline Habrophlebia sp. & $\mathrm{f}$ & $\mathrm{C}$ & $\mathrm{Cg}$ & 1.23 & 1.12 & 0.98 \\
\hline Habroleptoides sp. & $\mathrm{f}$ & $\mathrm{C}$ & $\mathrm{Cg}$ & 0.28 & 0.56 & 0.98 \\
\hline Ephemera danica & $\mathrm{c}$ & $\mathrm{C}$ & $\mathrm{Cg}$ & 0.04 & 0.00 & 0.49 \\
\hline Centroptilum luteolum & $\mathrm{f}$ & $\mathrm{D}$ & $\mathrm{Cg}$ & 0.32 & 1.12 & 0.49 \\
\hline Torleya major & $\mathrm{e}$ & $\mathrm{B}$ & $\mathrm{Cg}$ & 0.02 & 0.00 & 0.00 \\
\hline Paraleptophlebia sp. & $\mathrm{f}$ & $\mathrm{C}$ & $\mathrm{Cg}$ & 0.02 & 0.00 & 0.00 \\
\hline \multicolumn{7}{|l|}{ Trichoptera } \\
\hline Limnephilidae & $\mathrm{f}$ & $\mathrm{F}$ & Sh & 0.71 & 5.03 & 9.31 \\
\hline Potamophylax cingulatus & $\mathrm{f}$ & $\mathrm{F}$ & Sh & 0.06 & 0.00 & 0.00 \\
\hline Psychomyidae & $\mathrm{e}$ & $\mathrm{C}$ & $\mathrm{Cg}$ & 0.13 & 0.00 & 0.00 \\
\hline Glossosomatidae & $\mathrm{e}$ & $\mathrm{B}$ & $\mathrm{Sc}$ & 0.80 & 1.68 & 0.00 \\
\hline Leptoceridae & & & $\mathrm{Cg}$ & 0.06 & 0.56 & 0.00 \\
\hline Hyporhyacophila sp. & $\mathrm{c}$ & A & $\mathrm{P}$ & 0.04 & 0.00 & 0.00 \\
\hline Beraeidae & $\mathrm{e}$ & A & $\mathrm{Cg}$ & 0.02 & 0.00 & 0.00 \\
\hline Hydropsyche sp. & $\mathrm{e}$ & $\mathrm{C}$ & $\mathrm{F}$ & 1.04 & 0.00 & 0.00 \\
\hline Wormaldia sp. & $\mathrm{e}$ & A & $\mathrm{F}$ & 0.06 & 0.00 & 0.00 \\
\hline Goeridae & $\mathrm{f}$ & $\mathrm{C}$ & $\mathrm{Cg}$ & 0.02 & 0.00 & 0.00 \\
\hline Odontocerum albicorne & c & A & $\mathrm{Sh}$ & 0.30 & 0.00 & 0.00 \\
\hline Sericostoma $\mathrm{sp}$ & & & Sh & 0.06 & 0.00 & 0.00 \\
\hline \multicolumn{7}{|l|}{ Diptera } \\
\hline Anthomidae & $\mathrm{c}$ & $\mathrm{F}$ & $\mathrm{P}$ & 0.00 & 0.56 & 0.00 \\
\hline Atherix sp. & $\mathrm{d}$ & $\mathrm{C}$ & $\mathrm{P}$ & 0.09 & 0.00 & 0.00 \\
\hline Chironomidae & e & $\mathrm{F}$ & $\mathrm{Cg}$ & 10.78 & 29.6 & 32.3 \\
\hline Ceratopogonidae & $\mathrm{c}$ & $\mathrm{F}$ & $\mathrm{P}$ & 0.78 & 0.56 & 1.47 \\
\hline Psychodidae & e & $\mathrm{F}$ & $\mathrm{P}$ & 0.09 & 2.23 & 0.49 \\
\hline Anopheles sp. & $\mathrm{e}$ & $\mathrm{F}$ & $\mathrm{Cg}$ & 0.02 & 0.00 & 0.00 \\
\hline Simuliidae & $\mathrm{e}$ & $\mathrm{B}$ & $\mathrm{F}$ & 30.62 & 2.23 & 0.98 \\
\hline Dixidae & e & $\mathrm{F}$ & $\mathrm{P}$ & 0.04 & 0.00 & 0.00 \\
\hline Tipulidae & $\mathrm{c}$ & $\mathrm{D}$ & Sh & 1.10 & 0.00 & 0.49 \\
\hline Dolichopodidae & g & $\mathrm{F}$ & $\mathrm{P}$ & 0.00 & 0.56 & 0.98 \\
\hline Tabanidae & g & $\mathrm{F}$ & $\mathrm{P}$ & 0.15 & 0.00 & 0.00 \\
\hline Limoniidae & $\mathrm{c}$ & $\mathrm{D}$ & $\mathrm{P}$ & 0.54 & 0.00 & 1.47 \\
\hline Stratiomyidae & $\mathrm{e}$ & $\mathrm{D}$ & $\mathrm{P}$ & 0.06 & 2.23 & 1.96 \\
\hline
\end{tabular}


Table 2. (Continued)

\begin{tabular}{|c|c|c|c|c|c|c|}
\hline Taxa & Biol. traits & Ecol. traits ${ }^{\mathrm{a}}$ & $\mathrm{FFG}^{\mathrm{b}}$ & Natural riverbed & B-Traps & T-Traps \\
\hline \multicolumn{7}{|l|}{ Coleoptera } \\
\hline Hydrophilidae & $\mathrm{g}$ & G & $\mathrm{P}$ & 0.02 & 0.56 & 0.00 \\
\hline Helichus substriatus & $\mathrm{g}$ & G & Sh & 0.73 & 2.23 & 4.90 \\
\hline Hydraena andreinii & $\mathrm{g}$ & $\mathrm{D}$ & $\mathrm{Sc}$ & 0.91 & 0.00 & 0.49 \\
\hline Hydraena assimilis & $\mathrm{g}$ & $\mathrm{D}$ & $\mathrm{Sc}$ & 0.02 & 0.00 & 0.00 \\
\hline Hydraena truncata & $\mathrm{g}$ & $\mathrm{D}$ & Sc & 0.13 & 0.00 & 0.00 \\
\hline Hydraena subimpressa & $\mathrm{g}$ & $\mathrm{D}$ & $\mathrm{Sc}$ & 0.06 & 0.00 & 0.00 \\
\hline Hydraena devillei & $\mathrm{g}$ & $\mathrm{D}$ & $\mathrm{Sc}$ & 0.04 & 0.00 & 0.00 \\
\hline Gyrinidae (larvae) & $\mathrm{g}$ & G & $\mathrm{P}$ & 0.58 & 0.00 & 0.49 \\
\hline Elminthidae (larvae) & $\mathrm{g}$ & $\mathrm{D}$ & $\mathrm{Cg}$ & 0.15 & 0.00 & 0.49 \\
\hline Elminthidae & $\mathrm{g}$ & $\mathrm{D}$ & $\mathrm{Cg}$ & 0.15 & 0.00 & 0.00 \\
\hline Esolus sp. & $\mathrm{g}$ & $\mathrm{D}$ & $\mathrm{Cg}$ & 0.06 & 0.00 & 0.00 \\
\hline Helodidae (larvae) & $\mathrm{g}$ & G & $\mathrm{Sh}$ & 0.06 & 0.00 & 0.00 \\
\hline Dytiscidae & $\mathrm{g}$ & G & $\mathrm{P}$ & 0.00 & 0.00 & 0.98 \\
\hline \multicolumn{7}{|l|}{ Odonata } \\
\hline Onychogomphus sp. & $\mathrm{d}$ & $\mathrm{D}$ & $\mathrm{P}$ & 0.06 & 0.00 & 0.49 \\
\hline Orthetrum sp. & $\mathrm{d}$ & $\mathrm{F}$ & $\mathrm{P}$ & 0.09 & 0.00 & 0.00 \\
\hline Calopteryx sp. & $\mathrm{d}$ & $\mathrm{D}$ & $\mathrm{P}$ & 0.06 & 0.00 & 0.00 \\
\hline \multicolumn{7}{|l|}{ Heteroptera } \\
\hline Micronecta sp. & $\mathrm{e}$ & $\mathrm{D}$ & $\mathrm{P}$ & 3.82 & 0.00 & 0.00 \\
\hline \multicolumn{7}{|l|}{ Megaloptera } \\
\hline Sialis lutaria & $\mathrm{e}$ & G & $\mathrm{P}$ & 0.02 & 0.00 & 0.00 \\
\hline \multicolumn{7}{|l|}{ Hymenoptera } \\
\hline Agriotypus armatus & $\mathrm{e}$ & $\mathrm{C}$ & $P$ & 0.04 & 0.00 & 0.00 \\
\hline \multicolumn{7}{|l|}{ Planipenna } \\
\hline Osmylus fulvicephalus & $\mathrm{g}$ & $\mathrm{B}$ & $P$ & 0.00 & 0.56 & 0.00 \\
\hline \multicolumn{7}{|l|}{ Arachnida } \\
\hline Hydracarina & & & $\mathrm{P}$ & 0.37 & 0.00 & 0.00 \\
\hline \multicolumn{7}{|l|}{ Bivalva } \\
\hline Pisidium sp. & $\mathrm{b}$ & $\mathrm{D}$ & $\mathrm{F}$ & 0.02 & 0.56 & 0.00 \\
\hline \multicolumn{7}{|l|}{ Gastropoda } \\
\hline Lymnaea peregra & $\mathrm{c}$ & $\mathrm{F}$ & $\mathrm{Sc}$ & 0.06 & 0.00 & 0.98 \\
\hline \multicolumn{7}{|l|}{ Tricladida } \\
\hline Dugesia sp. & $\mathrm{c}$ & $\mathrm{D}$ & $\mathrm{P}$ & 7.41 & 26.26 & 12.25 \\
\hline \multicolumn{7}{|l|}{ Anellida } \\
\hline Eiseniella tetraedra & $\mathrm{h}$ & $\mathrm{D}$ & $\mathrm{Cg}$ & 1.60 & 5.03 & 1.47 \\
\hline Lumbricidae & $\mathrm{h}$ & $\mathrm{D}$ & $\mathrm{Cg}$ & 0.82 & 1.12 & 5.88 \\
\hline Lumbriculidae & $\mathrm{h}$ & $\mathrm{D}$ & $\mathrm{Cg}$ & 0.26 & 3.35 & 0.98 \\
\hline Naididae & $\mathrm{h}$ & $\mathrm{D}$ & $\mathrm{Cg}$ & 0.17 & 0.00 & 0.00 \\
\hline Tubificidae & $\mathrm{h}$ & $\mathrm{E}$ & $\mathrm{Cg}$ & 0.13 & 0.00 & 0.49 \\
\hline \multicolumn{7}{|l|}{ Nematomorpha } \\
\hline Gordius sp. & $\mathrm{b}$ & A & $P$ & 0.09 & 0.56 & 0.00 \\
\hline \multicolumn{7}{|l|}{ Nematoda } \\
\hline Mermithidae & $\mathrm{b}$ & A & $\mathrm{P}$ & 0.02 & 0.00 & 0.00 \\
\hline
\end{tabular}

Biological and ecological traits according to Usseglio-Polatera et al. (2000). Functional Feeding Groups according to Merritt \& Cummins (1996).

${ }^{a}$ Biological and ecological traits: see text.

${ }^{\mathrm{b}}$ FFG: functional feeding groups (Cg, collectors-gatherers; F, filterers; P, predators; Sc, scrapers; Sh, shredders). 

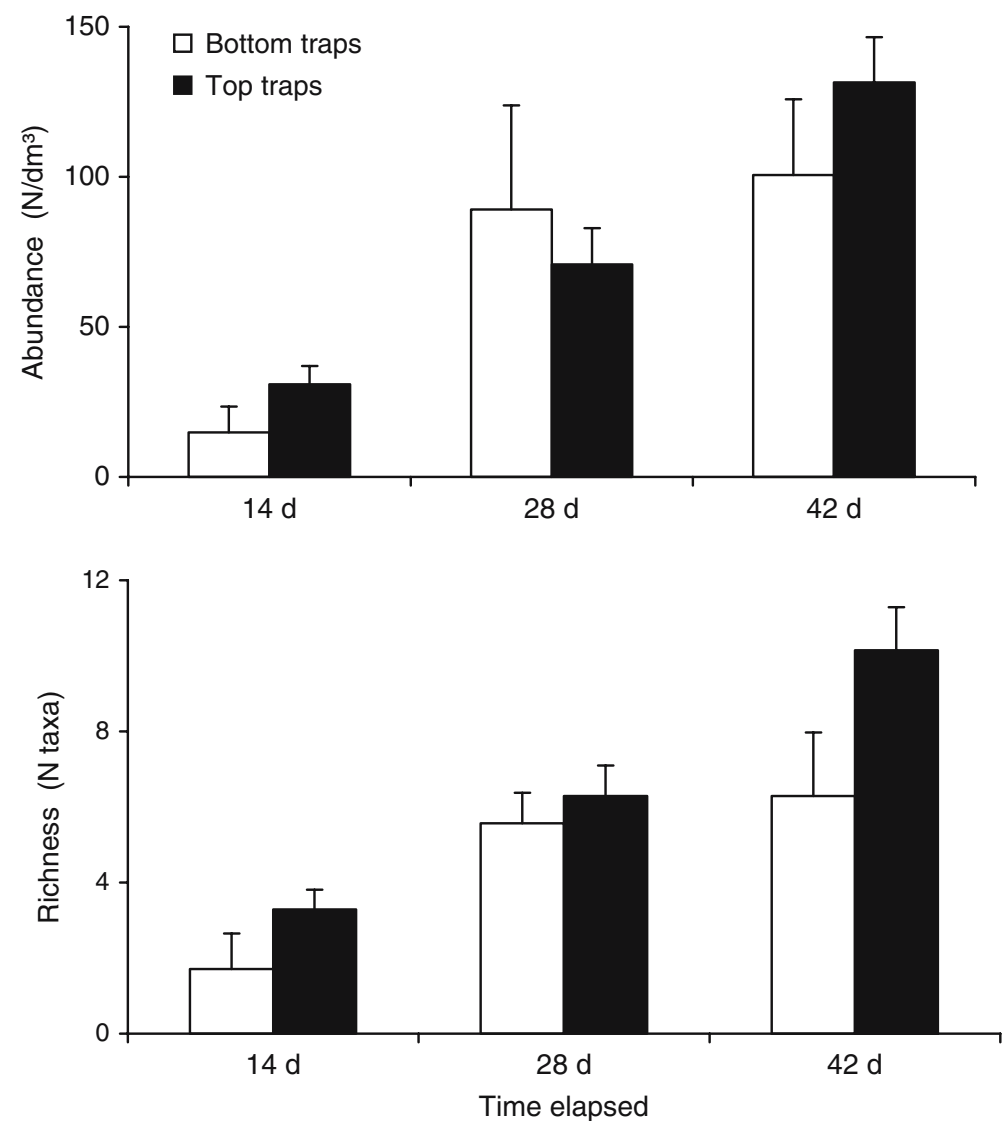

Figure 3. Time-related variation of mean abundance and community richness of macroinvertebrates found in top and bottom traps (mean $\pm 1 \mathrm{SE})$.

almost absent $(1.0 \%$ in T-traps and $1.2 \%$ in B-traps). When the functional composition of the interstitial substrata on the three sampling dates was considered, no significant differences were found between T- and B-traps (ANOVAs on arcsin-transformed percentages, all $p=$ n.s.). Moreover, the chronological evolution of the FFG composition did not differ significantly, except for scrapers which increased over time $\left(F_{2,41}=6.67\right.$, $p=0.007$ ) because of the development of biofilms.

The functional composition of the macroinvertebrate community in the natural riverbed was quite different from that in the interstitial traps. In the riffle riverbed, filterers were the most

Table 3. Comparison (mean $\pm \mathrm{SD}$, ANOVA tests) of abundance and taxonomic richness in the T- and B-traps

\begin{tabular}{|c|c|c|c|c|c|}
\hline \multirow[t]{2}{*}{ Time } & \multirow[t]{2}{*}{ Parameter } & \multicolumn{2}{|l|}{ Trap type } & \multicolumn{2}{|c|}{ Statistics } \\
\hline & & Top & Bottom & $F$ value & $p$ \\
\hline \multirow[t]{2}{*}{ Day 14} & Abundance $\left(\mathrm{N} / \mathrm{dm}^{3}\right)$ & $30.8 \pm 6.3$ & $14.8 \pm 8.6$ & 5.03 & $0.04^{*}$ \\
\hline & Richness (S) & $3.29 \pm 0.52$ & $1.71 \pm 0.94$ & 2.12 & 0.17 \\
\hline \multirow[t]{2}{*}{ Day 28} & Abundance $\left(\mathrm{N} / \mathrm{dm}^{3}\right)$ & $70.9 \pm 12.0$ & $89.12 \pm 34.6$ & 0.02 & 0.97 \\
\hline & Richness (S) & $6.29 \pm 0.80$ & $5.57 \pm 0.81$ & 0.389 & 0.54 \\
\hline \multirow[t]{2}{*}{ Day 42} & Abundance $\left(\mathrm{N} / \mathrm{dm}^{3}\right)$ & $131.4 \pm 15.0$ & $100.6 \pm 25.3$ & 2.26 & 0.16 \\
\hline & Richness (S) & $10.1 \pm 1.1$ & $6.20 \pm 1.2$ & 3.54 & $0.05^{*}$ \\
\hline
\end{tabular}




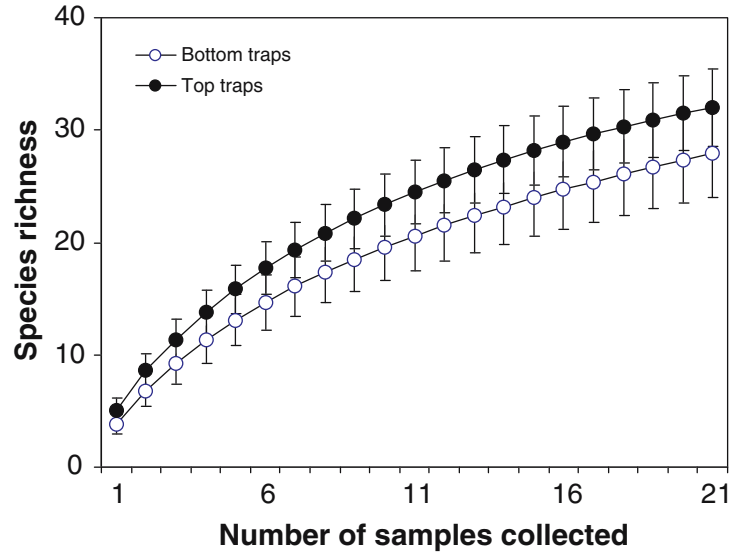

Figure 4. Taxa accumulation curves for invertebrates in interstitial traps bottom- and top-opened.

abundant FFG (31.7\% of individuals), followed by shredders $(24.2 \%)$ and collector-gatherers $(22.3 \%)$. In comparison to the interstitial trap assemblages, a higher number of scrapers were found $(10.3 \%)$ while predators were less abundant $(10.6 \%)$.
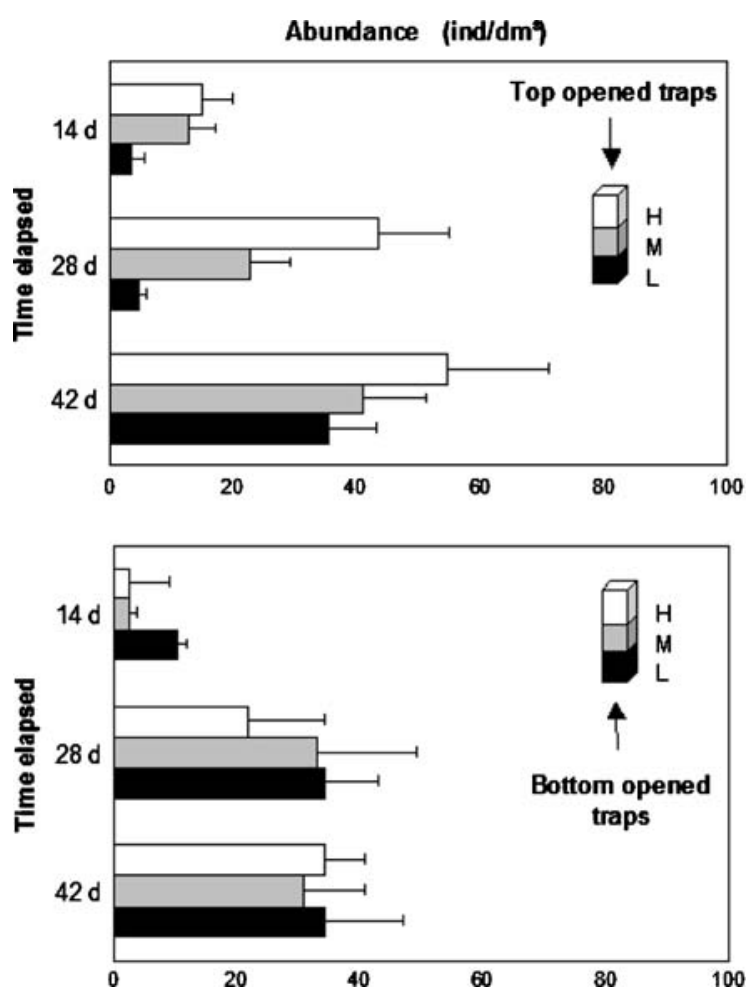

Figure 5. Number of organisms collected in the three baskets of each trap type of the different dates (mean $\pm \mathrm{SE}$ ).
Analysis of the biological and ecological traits of benthic macroinvertebrates (Usseglio-Polatera et al., 2000) showed no significant differences between $\mathrm{T}$ - and B-traps (all ANOVA $p=$ n.s.). Considering the biological traits, the most abundant taxa colonising interstitial substrata in both traps belonged to the 'e group' (small or mediumsized, short-lived crawlers, with aquatic respiration and cemented eggs: $42.2 \%$ ) followed by taxa belonging to the 'c group' (medium-sized, crawlers, with egg or larval dormancy: $21.2 \%$ ). Considering the ecological traits, the most abundant group was ' $F$ ' (organisms avoiding high current velocities: $46.7 \%$ ), followed by ' $D$ ' (organisms that live near the banks or in sidearms of lowland streams: $32.8 \%$ ). In the natural riverbed the most abundant biological group was the 'e group' (55.7\%) followed by the 'f group' (medium-sized, crawlers, shredders with aquatic respiration: $26.4 \%$ ), while the two most abundant ecological groups were ' $B$ ' (organisms living in rhithronic rheophilous environments: $54.7 \%)$ and ' $D$ ' $(18.9 \%)$.

\section{Discussion}

Since the studies of Kühtreiber (1934), Schwoerbel (1961, 1964), Hynes \& Coleman (1968) and Coleman \& Hynes (1970), it has been known that many benthic organisms occur below the depth usually sampled by benthic samplers. In this regard, the Ritrodat-Lunz project provided a substantial amount of interesting data (Bretschko, 1981; Bretschko \& Leichtfried, 1988), revealing diverse and intense interactions between the hyporheic interstitial layer and stream ecosystem.

The interstitial space of riverbed sediments is a main component of lotic systems and it is attracting growing interest (Gayraud \& Philippe, 2003) because of its importance in the dynamics of physical, chemical and biological processes. This zone is populated by many macroinvertebrate species. Yet, even though several studies have shown that most invertebrates inhabiting the interstitial area are present in the top $15 \mathrm{~cm}$ (Collier \& Scarsbrook, 2000), little is known about the movements and colonisation direction within this zone.

We detected a clear time-dependent colonisation process in our interstitial traps, with increasing taxa richness and organism density in both trap 
Table 4. Indicator values, habitat abundance and fidelity for macroinvertebrates collected: (a) from T- and B-traps; (b) in the first period (early colonisers) and the last period (late colonisers)

\begin{tabular}{llll}
\hline Taxa & Indicator value & T-traps & B-traps \\
\hline (a) $^{\mathrm{A}}$ & & & $1 / 1$ \\
Baetis sp. & 49.47 & $17 / 11$ & $4 / 4$ \\
Capnia bifrons & 28.57 & $24 / 7$ & $13 / 8$ \\
Brachyptera sp. & 35.37 & $1 / 1$ & Last period \\
\hline Taxa & Indicator value & First period & $11 / 6$ \\
\hline (b) $^{\mathrm{B}}$ & & & $13 / 8$ \\
Baetis sp. & 42.86 & $0 / 0$ & $8 / 5$ \\
Capnia bifrons & 57.14 & $0 / 0$ & $11 / 6$ \\
Eiseniella tetraedra & 35.71 & $0 / 0$ & $24 / 7$ \\
Helichus substriatum & 42.86 & $0 / 0$ & $2 / 2$ \\
Limnephilidae & 46.15 & & \\
\hline
\end{tabular}

Traps data show the total number of individuals collected and the number of traps where each single taxon was found.

${ }^{\text {A }}$ Only 3 out of 42 taxa with an indicator value 25 are reported.

${ }^{\mathrm{B}}$ Only 5 out of 42 taxa with an indicator value $>25$ are reported.

types during the study period. According to Panek (1991, 1994), who recorded active movements in all directions, we detected bi-directional vertical active migrations, with no differences in the density and richness of invertebrate assemblages between the bottom-up and top-down migrations. This finding indicates that, in our study area, the first $15 \mathrm{~cm}$ of the substratum layer is a very rich habitat. The depth of the hyporheic interstitial layer is variable in gravel riverbeds, and it can fluctuate among different streams because of the influence of some abiotic parameters, such as oxygen, porosity and grain size distribution (Bretschko, 1994). The increase of organisms was very rapid in both trap types. Macroinvertebrate densities varied from a minimum of 0 ind. $/ \mathrm{dm}^{3}$ after 14 days to a maximum to 288 ind./ $\mathrm{dm}^{3}$ after 42 days. Final mean densities of macroinvertebrates were similar to those found in other European gravel riffles (Weigelhofer \& Waringer, 2003).

Scarsbrook (1995) reported three distinct patterns of vertical distribution of macroinvertebrates in the sub-substratum: organisms with a pattern of reduced abundance with depth, organisms with uniform distribution and organisms that increased in density with depth. We detected a uniform distribution for all taxa at the end of the study period, with no significant preference for a particular depth.

Our study supports the hypothesis that the interstitial zone is an important habitat for stream macrobenthos (Del Rosario \& Resh, 2000), although it may not be used by all taxa. Chironomidae constituted almost a third of the total number of organisms in the interstitial zone, representing the most abundant benthic group, as reported in other studies (Weigelhofer \& Waringer, 2003). Flatworms Dugesia sp. were also abundant: they actively move in this zone, gliding within substrate elements because of their flattened body. Limnephilidae were also conspicuously present, especially with small instars; the small size of juveniles probably allows them to colonise this particular habitat, while large-cased mature individuals are almost absent in the interstitial zone. Another well represented group is Plecoptera, with two typical winter stoneflies: Brachyptera monilicornis, an endangered and extremely localised species (Agosta et al., 2000), and Capnia bifrons, known to colonise the substratum in different periods of its life cycle (Hynes, 1979). Interestingly, very few rheophilic taxa were found in the interstitial zone, even though all traps were located in a riffle: these organisms have an inherent need for current, either because they rely on it for feeding purposes or because their respiratory requirements demand it, and this need cannot be satisfied within the elements of the riverbed.

Our analysis of the functional, ecological and biological characteristics of taxa found in the subsurface zone showed that interstitial colonisers are: 
(a) small or medium-sized (sensu Usseglio-Polatera et al., 2000); (b) with generalist trophic roles, mainly detritivores (collector-gatherers or shredders), likely feeding on detritus and biofilms, or predators; (c) mostly with flexible, cylindricalshaped or elongated bodies; (d) with an ecological preference for low-flowing environments and lentic microhabitats; (e) crawlers or walkers. Due to the lack or paucity of primary production in the subsubstratum (Müllner \& Schagerl, 2003), invertebrates probably feed on detritus and biofilms derived mainly from allochthonous inputs and on the associated microflora: fine particulate organic matter sustains a high number of collectorgatherers while coarse organic matter attracts shredders. We found that some large shredders (e.g. Brachyptera sp.) and collectors (e.g. Eiseniella tetraedra) were late colonisers, which likely colonised the traps when the amount of organic matter became more substantial and biofilms were well developed. The high number of predators in the sub-substratum, compared with their occurrence in surface streambed communities, can be related to a 'numerical response', sensu Giller \& Malmqvist (1998): hunting predators likely aggregate in patches with high prey density, particularly when prey are poorly mobile, as in the interstitial zone. The numerical increase of scrapers during the study period was likely due to the increased presence of biofilms on the substratum elements. In bed sediments, biofilms are major organic sources and they also represent important retention mechanisms: Leichtfried (1991, 1994, 1995) demonstrated the importance of this element in the ecology of hyporheic interstitial biocoenoses. In this context, our results confirm the findings of other studies (Hose et al., 2005).

Our study demonstrated that, in Apennine lotic systems, gravel riverbeds can sustain rich and diversified invertebrate assemblages that actively move within the substratum and have a composition and structure quite different from the surface streambed communities. Interstitial habitats are an important component of the biological and ecological system of small creeks. The interstitial zone represents a unique habitat for many organisms, acting as a source of colonisation movements; this zone is highly permeable to invertebrates and can be an important medium connecting the groundwater layer with the stream surface and also connecting different stream reaches, for example during low-flow conditions and droughts. Moreover, our analysis of the functional organisation of interstitial assemblages suggested that this area plays a key role in stream metabolism, allowing a large portion of the allochthonous organic matter to enter the lotic food system.

The maintenance of natural substratum characteristics is essential for the correct functioning of the entire stream system. Most studies agree that the penetration of organisms into deeper sediment layers depends mainly on the availability of interstitial habitats, rendering the amount of fine particles in the interstices a key determinant of hyporheic colonisation (Maridet et al., 1996). In the last few decades, alteration of the morphology and hydrology of many streams and rivers has modified the natural characteristics of lotic habitats: one of the most dangerous effects of canalisation is the alteration of transport and sedimentation processes. Fine sediment accumulations in large tracts of a river may clog the interstices, restrict hyporheic water exchange and lead to a decrease in oxygen (Brunke, 1999). These elements could reduce both the density and taxa richness of macroinvertebrates living in the substratum, with serious biological and functional effects on the whole stream system and a decline of the self-purification capacity of the stream.

\section{Acknowledgements}

We thank P. Agosta, R. Castellaro, M. Pessino, R. Rua and F. Sgariboldi for help during field sampling. We also thank G. Ferro for the determination of Hydraenidae. The study was supported by MIUR $60 \%$ and by Regione Piemonte CIPE 'Ricerca scientifica applicata' grants.

\section{References}

Agosta, P., T. Bo, S. Fenoglio \& A. Morisi, 2001. Brachyptera monilicornis (Pictet, 1842): nuove segnalazioni per il Piemonte (Plecoptera, Taeniopterygidae). Rivista Piemontese di Storia Naturale 22: 151-154.

Boulton, A. J., 1989. Over-summering refuges of aquatic macroinvertebrates in two intermittent streams in central Victoria. Transactions of the Royal Society of South Australia 113: 23-34. 
Boulton, A. J., S. Findlay, P. Marmonier, E. H. Staneley \& H. M. Vallet, 1998. The functional significance of the hyporheic zone in streams and rivers. Annual Review of Ecology and Systematics 29: 59-81.

Bretschko, G., 1979. The new research concept of the Biological Station Lunz of the Austrian Academy of Sciences. Stygo News 2: 9-10.

Bretschko, G., 1981. Vertical distribution of zoobenthos in an alpine brook of the Ritrodat-Lunz study area. Verhandlungen der Internationalen Vereinigung für Theoretische und Angewandte Limnologie 21: 873-876.

Bretschko, G., 1985. Quantitative sampling of the fauna of Gravel-Streams (Project Ritrodat-Lunz). Verhandlungen der Internationalen Vereinigung für Theoretische und Angewandte Limnologie 22: 2049-2052.

Bretschko, G., 1990. The effect of escape reactions on the quantitative sampling of gravel stream fauna. Archiv für Hydrobiologie 120: 41-49.

Bretschko, G., 1992. Differentiation between epigeic and hypogeic fauna in gravel streams. Regulated Rivers 7: 17-22.

Bretschko, G., 1994. Bedsediment extension, grain shape and size distribution. Verhandlungen der Internationalen Vereinigung für Theoretische und Angewandte Limnologie 25: 1631-1635.

Bretschko, G., 1995. The ecological importance of stream bedsediments, regardlessof whether or not they are inundated. Folia Fac. Sci. Nat. Univ. Masarykianae Brunensis, Biologia 1: 5-17.

Bretschko, G. \& M. Leichtfried, 1988. Distribution of organic matter and fauna in a second order, alpine gravel stream (Ritrodat-Lunz study area, Austria). Verhandlungen der Internationalen Vereinigung für Theoretische und Angewandte Limnologie 23: 1333-1339.

Brittain, J. E. \& T. J. Eikeland, 1988. Invertebrate drift - a review. Hydrobiologia 166: 77-93.

Brunke, M., 1999. Colmation and depth filtration within streambeds: retention of particles in hyporheic interstices. International Review of Hydrobiology 84: 99-117.

Coleman, M. J. \& H. B. N. Hynes, 1970. The life histories of some Plecoptera and Ephemeroptera in a southern Ontario stream. Canadian Journal of Zoology 48: 1333-1339.

Colwell, R. K., 1997. EstimateS: statistical estimation of species richness and shared species from samples. Version $6.0 \mathrm{bl}$.

Collier, K. J. \& M. R. Scarsbrook, 2000. Use of riparian and hyporheic habitats. In Collier, K. J. \& M. J. Winterbourn (eds), New Zealand Stream Invertebrates: Ecology and Implications for Management. New Zealand Limnological Society, Christchurch: 179-206.

Del Rosario, R. B. \& V. H. Resh, 2000. Invertebrates in intermittent and perennial streams: is the hyporheic zone a refuge from drying? Journal of North American Benthological Society 19: 680-696.

Delucchi, C. M., 1989. Movement patterns of invertebrates in temporary and permanent streams. Oecologia 78: 199-207.

Dole-Olivier, M. J. \& P. Marmonier, 1992. Patch distribution of interstitial communities: prevailing factors. Freshwater Biology 27: 177-191.

Dole-Olivier, M. J., P. Marmonier \& J. L. Beffy, 1997. Response of invertebrates to lotic disturbance: is the hyporheic zone a patchy refugium? Freshwater Biology 37: 257-276.
Dufrêne, M., 1998. IndVal or how to identify indicator species of a sample typology? Version 2.0. User's Guide and application published at: http: //mrw.wallonie.be/dgrne/sibw/ outils/indval/home.html.

Dufrêne, M. \& P. Legendre, 1997. Species assemblages and indicator species: the need for a flexible asymmetrical approach. Ecological Monografy 67: 345-366.

Fenoglio, S., P. Agosta, T. Bo \& M. Cucco, 2002. Field experiments on colonisation and movements of stream invertebrates in an Apennine river (Visone, NW Italy). Hydrobiologia 474: 125-130.

Fenoglio, S., T. Bo, G. Gallina \& M. Cucco, 2004. Vertical distribution in the water column of drifting stream macroinvertebrates. Journal of Freshwater Ecology 19: 485-492.

Gayraud, S. \& M. Philippe, 2003. Influence of bed-sediment features on the interstitial habitat available for macroinvertebrates in 15 French streams. International Review of Hydrobiology 88: 77-93.

Ghetti, P. F., 1997. Handbook for the Application of the Extended Biotic Index (In italian). Provincia autonoma di Trento, Trento, Italy.

Giller, P. S. \& B. Malmqvist, 1998. The Biology of Streams and Rivers. Oxford University Press.

Hauer, F. R. \& G. A. Lamberti, 1996. Methods in Stream Ecology. Academic Press, San Diego, CA.

Hynes, H. B. N., 1974. Further studies on the distribution of stream animals within the substratum. Limnology and Oceanography 19: 92-99.

Hynes, H. B. N., 1979. The Ecology of Running Waters. Downsview, Ontario.

Hynes, H. B. N. \& M. J. Coleman, 1968. A simple method of assessing the annual production of stream benthos. Limnology and Oceanographic 13: 569-573.

Hose, G. C., P. Jones \& R. P. Lim, 2005. Hyporheic macroinvertebrates in riffle and pool areas of temporary streams in south eastern Australia. Hydrobiologia 532: 81-90.

Huryn, A. D., 1996. An appraisal of the Allen paradox in a New Zealand trout stream. Limnology and Oceanographic 41: $243-252$.

Kühtreiber, J., 1934. Die Plekopterenfauna Nordtirols. Ph.D. Thesis, University of Innsbruck, Innsbruck, Austria.

Jacobi, G. Z. \& S. J. Cary, 1996. Winter stoneflies (Plecoptera) in seasonal habitats in New Mexico, USA. Journal of North American Benthological Society 15: 690-699.

Leichtfried, M., 1991. POM in bedsediments of a gravel stream (RITRODAT-Lunz study area, Austria). Verhandlungen der Internationalen Vereinigung für Theoretische und Angewandte Limnologie 24: 1921-1925.

Leichtfried, M., 1994. Protein measurements in bedsediments, an important compartement of POM in a 2nd order gravel stream (Project Ritrodat-Lunz, AUSTRIA, Europe). Verhandlungen der Internationalen Vereinigung für Theoretische und Angewandte Limnologie 25: 1636-1640.

Leichtfried, M., 1995. Organic matter in bedsediments - an energy source for lotic ecosystems (a compilation of a long term study). Folia Fac. Sci. Nat. Univ. Masarykianae Brunensis, Biologia 91: 77-93.

Madsen, B. L. \& I. Butz, 1976. Population movements of adult Brachyptera risi (Plecoptera). Oikos 27: 273-280. 
Mackay, R. J., 1992. Colonization by lotic macroinvertebrates: a review of processes and patterns. Canadian Journal of Fisheries and Aquatic Sciences 49: 617-628.

Maridet, L., M. Philippe, J. G. Wasson \& J. Mathieu, 1996. Spatial and temporal distribution of stream macroinvertebrates and trophic variables within the bed sediment of three streams differing by their morphology and riparian vegetation. Archiv für Hydrobiologie 136: 41-64.

Marmonier, P., M. J. Dole-Olivier \& M. Creuze des Chatelliers, 1992. Spatial distribution of interstitial assemblages in the floodplain of the Rhône River. Regulated Rivers 7: 75-82.

Merritt, R. W. \& K. W. Cummins, 1996. An Introduction to the Aquatic Insects of North America. Kendall/Hunt, Dubuque, IO.

Muller, K., 1954. Investigations on the organic drift in north Swedish stream. Report Institute of Freshwater Research Drottiningholm 35: 133-148.

Muller, K., 1982. The colonization cycle of freshwater insects. Oecologia 52: 202-207.

Müllner, A. N. \& M. Schagerl, 2003. Abundance and vertical distribution of the phytobenthic community within a pool and riffle sequence of an Alpine gravel stream. International Review of Hydrobiology 88: 243-254.

Orghidan, T., 1959. Ein neuer Lebensraum des unterirdischen Wassers, der hyporheische biotop. Archiv für Hydrobiologie 55: 392-414.

Panek, K. L. J., 1991. Migrations of the macrozoobenthos within the bed sediments of a gravel stream (Ritrodat-Lunz study area, Austria). Verhandlungen der Internationalen Vereinigung für Theoretische und Angewandte Limnologie 24: 1944-1947.

Panek, K. L. J., 1994. Depth boundaries of bedsediments in an alpine stream (Ritrodat-Lunz study area, Austria). Verhandlungen der Internationalen Vereinigung für Theoretische und Angewandte Limnologie 25: 1646-1648.

Scarsbrook, M. R., 1995. Disturbance and spatial refugia in stream communities. Ph.D. Thesis, University of Otago, Dunedin, New Zeland.
Schwoerbel, J., 1961. Hungarohydracarus subterraneus italicus nov. ssp. die erste Süwasserbilme (Hydracnellae) aus dem hyporheischen Grundwasser. Memorie dell' Istituto Italiano di Idrobiologia, Pallanza 13: 115-124.

Schwoerbel, J., 1964. Die Bedeutung des Hyporheals für die benthischen Lebensgemeinschaften des Fliess-gewassers. Verhandlungen der Internationalen Vereinigung für Theoretische und Angewandte Limnologie 15: 215-226.

Söderström, O., 1987. Upstream movements of invertebrates in running waters - a review. Archiv für Hydrobiologie 111: 197-208.

Townsend, C. R. \& A. G. Hildrew, 1976. Field experiments on the drifting, colonization and continuous redistribution of stream benthos. Journal of Animal Ecology 45: 759-772.

Usseglio-Polatera, P., M. Bournaud, P. Richoux \& H. Tachet, 2000. Biological and ecological traits of benthic fresh-water macroinvertebrates: relationships and definition of groups with similar traits. Freshwater Biology 43: 175-205.

Vallett, H. M., C. C. Hakenkamp \& A. J. Boulton, 1993. Perspectives on the hyporheic zone: integrating hydrology and biology. Introduction. Journal of North American Benthological Society 12: 40-43.

Vannote, R. L., G. W. Minshall, K. W. Cummins, J. R. Sedell \& C. E. Cushing, 1980. The river continuum concept. Canadian Journal of Fisheries and Aquatic Sciences 37: 130-137.

Weigelhofer, G. \& J. Waringer, 2003. Vertical distribution of benthic macroinvertebrates in riffles versus deep runs with differing contents of fine sediments (Weidlingbach, Austria). International Review of Hydrobiology 88: 304-313.

Williams, D. D. \& H. B. N. Hynes, 1976. The recolonization mechanisms of stream benthos. Oikos 27: 265-272.

White, D. S., 1993. Perspectives on defining and delineating hyporheic zones. Journal of North American Benthological Society 12: 61-69. 